\title{
Analysis and design solutions for a 4x4 ATV with an electromechanical transmission
}

\author{
Kirill Evseev*, Alexey Dyakov, and Vadim Pushtakov \\ Bauman Moscow State Technical University, 5/1, 2-ya Baumanskaya street, Moscow, 105005, Russia
}

\begin{abstract}
The article provides a review and analysis of the current state of development of $4 \times 4$ ATVs and the scope of the developed ATV, a comparison of ATVs with mechanical and electromechanical transmissions, as well as their technical characteristics. The selection and justification of the design solutions for a $4 \times 4$ ATV with an electromechanical transmission are given on the basis of the following electric drive schemes considered in the article: "Electric motor instead of ICE", "Motor axis", "Electric motorhalf axis". The general design solutions of the ATV being developed is also presented based on the selected electric drive scheme.
\end{abstract}

\section{Purpose and scope of the developed product}

The developed ATV with an electromechanical driveline and $4 \mathrm{x} 4$ wheel formula is designed to transport people and small loads in off-road conditions, except for virgin snow with a depth of snow cover of more than $250 \mathrm{~mm}$ and is characterized by the ability to overcome natural and artificial obstacles such as slopes, slopes, trenches [1].

The structure of a $4 \times 4$ ATV with an electromechanical driveline includes the following main components $[2,3]$ :

- traction electric motor;

- motor controller;

- traction batteries;

- transfer box;

- final drive and differential;

- suspension system;

- steering system;

- brake system;

- electrical equipment;

- frame.

Currently, the following main classes of ATVs have been formed: utilitarian, tourist, and boost. According to this classification, the developed ATV belongs to the utilitarian class. A distinctive feature of the developed vehicle is the rejection of the internal combustion engine, which is the main source of noise in the ATV.

* Corresponding author: $\underline{\mathrm{kb} \_ \text {evseev@bmstu.ru }}$ 


\section{Overview and analysis of the current state of development of 4x4 ATVs}

The requirements for the characteristics of the developed ATV were formulated on the basis of an analysis of the technical level of ATVs of a similar class presented on the market with both mechanical and electromechanical transmissions, the design of which is devoted to the work [4]. Technical characteristics of the tested ATVs with a mechanical driveline are given in Table 1. Technical characteristics of ATVs with an electromechanical driveline are given in Table 2. For comparison, Table 2 shows the characteristics of the developed ATV and the serial ATV of JSC "Russkaya mekhanika" RM 650 [5-12].

Based on the analysis of the data given in table 2, we can draw the following conclusions for electromechanical ATVs:

- the scheme "Electric motor instead of internal combustion engine" was applied on all tested ATVs;

- average power of the traction electric motor is $15 \mathrm{~kW}$, minimum $14 \mathrm{~kW}$, maximum $19.6 \mathrm{~kW}$.

- voltage in the traction electric drive circuit $72 \mathrm{~V}$ for all examined ATVs;

- Li-ion batteries, battery capacity of $100 \mathrm{Ah}$, rated voltage of $72 \mathrm{~V}$ were used on all examined ATVs;

- the driveline of all ATVs is two-stage, there is no variator;

- average maximum speed is $62.6 \mathrm{~km} / \mathrm{h}$, maximum - $58 \mathrm{~km} / \mathrm{h}$;

- power reserve varies from 96 to $25 \mathrm{~km}$ at an average speed of $40 \mathrm{~km} / \mathrm{h}$;

- average dry weight is $450 \mathrm{~kg}$, ATVs are single.

Based on a comparison of the characteristics of ATVs with a mechanical and electromechanical driveline it can be concluded that currently ATVs with an electromechanical driveline are inferior to ATVs with a mechanical driveline in such parameters as:

- maximum driving range;

- power-to-weight ratio;

- transport weight.

At the same time, ATVs with an electromechanical driveline have the following advantages:

- less noise during operation;

- greater traction force on wheels at low speeds;

- are more environmentally friendly.

The aim of this work is to create an ATV with an electromechanical driveline with characteristics not inferior to the characteristics of an ATV with a mechanical driveline. In this regard, a traction motor with a power of $32 \mathrm{~kW}$ was selected which is close in magnitude to the power of the internal combustion engine of the ATV RM $650(31 \mathrm{~kW})$ and an energy storage device that provides a cruising range of about $70 \mathrm{~km}$ in the calculated driving cycle at a speed of $60 \mathrm{~km} / \mathrm{h}$. 
Table 1. Technical characteristics of the examined ATVs with a mechanical driveline.

\begin{tabular}{|c|c|c|c|c|c|c|}
\hline Model & $\begin{array}{c}\text { Arctic Cat } \\
\text { Alterra } \\
500\end{array}$ & $\begin{array}{c}\text { Arctic Cat } \\
\text { Alterra } \\
\text { TRV 550 } \\
\text { XT }\end{array}$ & $\begin{array}{c}\text { Honda } \\
\text { FOURTRA } \\
\mathrm{X} \\
\text { FOREMA } \\
\mathrm{N} \\
\text { RUBICON } \\
\end{array}$ & $\begin{array}{c}\text { Polaris } \\
\text { SPORTSM } \\
\text { AN } \\
\text { TOURING } \\
850 \mathrm{SP}\end{array}$ & RM 650-2 & RM 500 \\
\hline $\begin{array}{c}\text { Dry } \\
\text { weight, } \\
\text { kg }\end{array}$ & 278 & 329 & $\begin{array}{l}323 \text { (fully- } \\
\text { equipped) }\end{array}$ & 365 & 375 & 388 \\
\hline $\begin{array}{c}\text { Payload, } \\
\text { kg }\end{array}$ & 204 & 136 & & 261 & $\begin{array}{c}120 \\
\text { (baggage } \\
\text { hold) }\end{array}$ & $\begin{array}{c}120 \\
\text { (baggage } \\
\text { hold) }\end{array}$ \\
\hline $\begin{array}{c}\text { Drawbar } \\
\text { trailer } \\
\text { weight, } \\
\text { kg }\end{array}$ & 476 & 476 & 600 & 680 & 250 & 250 \\
\hline $\begin{array}{l}\text { Dimensi } \\
\text { ons, } \mathrm{mm}\end{array}$ & $\begin{array}{c}2120 x 460 x \\
1170\end{array}$ & $\begin{array}{c}2315 \times 1215 \\
\times 1458\end{array}$ & $\begin{array}{c}2146 \times 1204 \\
\times 1234\end{array}$ & $\begin{array}{c}2197 \times 1209 \\
\times 1479\end{array}$ & $\begin{array}{l}2320 \times 1245 \\
\times 1255\end{array}$ & $\begin{array}{c}2400 \times 1245 \\
\times 1255\end{array}$ \\
\hline $\begin{array}{c}\text { Engine } \\
\text { cubic } \\
\text { capacity } \\
\mathrm{cm}^{3}\end{array}$ & 443 & 545 & 475 & 850 & 622 & 503 \\
\hline $\begin{array}{l}\text { Engine } \\
\text { power, } \\
\mathrm{kW}\end{array}$ & - & - & - & 55 & 31 & 30 \\
\hline $\begin{array}{l}\text { Number } \\
\text { of seats }\end{array}$ & 1 & 2 & 2 & 2 & 2 & 2 \\
\hline $\begin{array}{c}\text { Drivelin } \\
\mathrm{e}\end{array}$ & $\begin{array}{l}\text { Variator } \\
2 / 4 \mathrm{WD}\end{array}$ & $\begin{array}{c}\text { Variator } \\
\text { 2/4WD, } \\
\text { front } \\
\text { differential } \\
\text { lock }\end{array}$ & $\begin{array}{l}5 \text { fast-speed } \\
\text { power- } \\
\text { operated } \\
\text { with } 2 \\
\text { clutches }\end{array}$ & $\begin{array}{l}\text { Variator } \\
2 / 4 \mathrm{WD}\end{array}$ & $\begin{array}{c}\text { Variator } \\
2 / 4 \mathrm{WD}, \\
\text { front } \\
\text { differential } \\
\text { lock }\end{array}$ & $\begin{array}{c}\text { Variator } \\
\text { 2/4WD, } \\
\text { front } \\
\text { differential } \\
\text { lock }\end{array}$ \\
\hline $\begin{array}{l}\text { Wheel } \\
\text { diameter } \\
, \mathrm{mm}\end{array}$ & 635 & 635 & 635 & 660 & 660 & 660 \\
\hline $\begin{array}{c}\text { Fuel } \\
\text { tank } \\
\text { volume, } \\
1\end{array}$ & 16 & 20,1 & 17,7 & 19,9 & 24 & 24 \\
\hline $\begin{array}{c}\text { Maximu } \\
\text { m } \\
\text { speed, } \\
\mathrm{km} / \mathrm{h}\end{array}$ & - & - & - & - & 85 & 80 \\
\hline
\end{tabular}


Table 2. Technical characteristics of the examined ATVs with an electromechanical driveline.

\begin{tabular}{|c|c|c|c|c|c|}
\hline ATV name & $\begin{array}{l}\text { CITADEL } \\
\text { PRO ATV }\end{array}$ & $\begin{array}{l}\text { Eco Charger } \\
\text { Eliminator }\end{array}$ & $\begin{array}{l}\text { Eco Charger } \\
\text { Dominator }\end{array}$ & RM 650-2 & $\begin{array}{l}\text { Developed } \\
\text { ATV }\end{array}$ \\
\hline \multicolumn{6}{|l|}{$\begin{array}{l}\text { General } \\
\text { form }\end{array}$} \\
\hline $\begin{array}{c}\text { Dimensions, } \\
\mathrm{mm}\end{array}$ & $\begin{array}{l}\text { Length: } \\
2235\end{array}$ & $\begin{array}{c}2100 \times 1150 \times 1 \\
170\end{array}$ & $\begin{array}{c}1980 \times 1140 x 1 \\
150\end{array}$ & $\begin{array}{c}2320 \times 1245 \times 1 \\
255\end{array}$ & $\begin{array}{c}2320 \times 1245 \times 1 \\
255\end{array}$ \\
\hline $\begin{array}{c}\text { Wheelbase, } \\
\mathrm{mm}\end{array}$ & 1321 & 1290 & 1280 & 1500 & 1500 \\
\hline $\begin{array}{l}\text { Weight } \\
\text { (dry), kg }\end{array}$ & 465 & 491 & 395 & 375 & 500 \\
\hline Payload, kg & - & - & - & 250 & 200 \\
\hline $\begin{array}{c}\text { Seating } \\
\text { accommodat } \\
\text { ion } \\
\end{array}$ & 1 & 1 & 1 & 2 & 2 \\
\hline Engine, qty. & $\begin{array}{c}14 \mathrm{~kW}, 72 \mathrm{~V} \\
19,6 \mathrm{~kW} \\
96 \mathrm{~V} \\
1\end{array}$ & $\begin{array}{c}15 \mathrm{~kW}, 72 \mathrm{~V} \\
1\end{array}$ & $\begin{array}{c}15 \mathrm{~kW}, 72 \mathrm{~V} \\
1\end{array}$ & $\begin{array}{c}622 \mathrm{cc}, 31 \\
\mathrm{~kW} \\
1\end{array}$ & $\begin{array}{c}32 \mathrm{~kW}, 115- \\
135 \mathrm{~V} \\
1\end{array}$ \\
\hline $\begin{array}{c}\text { Driving } \\
\text { range, } \\
\mathrm{km}\end{array}$ & $96 \mathrm{~km}$ & $\begin{array}{c}25 \mathrm{~km} \text { at a } \\
\text { speed of } 40 \\
\mathrm{~km} / \mathrm{h}\end{array}$ & $\begin{array}{c}25 \mathrm{~km} \text { at a } \\
\text { speed of } 40 \\
\mathrm{~km} / \mathrm{h}\end{array}$ & $>250$ & $\begin{array}{c}70 \mathrm{~km} \text { at a } \\
\text { speed of } 50 \\
\mathrm{~km} / \mathrm{h}\end{array}$ \\
\hline Driveline & $\begin{array}{l}\text { Two-speed } \\
\text { automatic } \\
\text { with plug-in } \\
\text { four-wheel } \\
\text { drive }\end{array}$ & $\begin{array}{l}\text { Two-speed } \\
\text { automatic } \\
\text { with plug-in } \\
\text { four-wheel } \\
\text { drive }\end{array}$ & $\begin{array}{l}\text { Two-speed } \\
\text { automatic } \\
\text { with plug-in } \\
\text { four-wheel } \\
\text { drive }\end{array}$ & $\begin{array}{c}\text { Variable } \\
\text { speed drive } \\
2 / 4 \mathrm{WD}, \\
\text { front } \\
\text { differential } \\
\text { lock } \\
\end{array}$ & $\begin{array}{l}\text { Two-speed } \\
\text { automatic } \\
\text { with plug-in } \\
\text { four-wheel } \\
\text { drive }\end{array}$ \\
\hline Wheels & - & $\begin{array}{c}185 / 55-14 \\
(586 \mathrm{~mm})\end{array}$ & $\begin{array}{r}25 \times 10-12 \\
(635 \mathrm{~mm})\end{array}$ & $660 \mathrm{~mm}$ & - \\
\hline $\begin{array}{l}\text { Maximum } \\
\text { speed, km / } \\
\mathrm{h}\end{array}$ & 72 & 58 & 58 & 85 & 80 \\
\hline Battery & $\begin{array}{c}\text { Li-ion, } 100 \\
\text { A-h, 72B }\end{array}$ & $\begin{array}{c}\text { Li-ion, } 100 \\
\text { A-h, } 72 \mathrm{~V}\end{array}$ & $\begin{array}{c}\text { Li-ion, } 100 \\
\text { A-h, } 72 \mathrm{~V}\end{array}$ & 85 & $\begin{array}{c}\text { Li-ion, 81 A- } \\
\text { h, 117V }\end{array}$ \\
\hline
\end{tabular}

\section{Analysis of existing drive schemes}

Many electric vehicles use driveline chains. Currently, the following drive schemes are used:

- The electric "Electric motor instead of ICE" (Fig. 1, a) corresponds to the generally accepted principles of vehicle design solutions with the replacement of the internal combustion engine by a traction electric motor. The scheme has the following advantages:

1) the ability to use the full power of the power plant when driving on the rise, which eliminates the use of oversized electric motors;

2) the use of one traction inverter while maintaining the possibility of branching power flows into the account of a mechanical driveline (unified with an ATV equipped with an internal combustion engine) and a backup electric brake system;

3 ) the most rational design solutions of the hydraulic cooling system, without the use of extended flexible pipes (tubes), all of whose components are in close proximity to the electric motor; 
4) the smallest total mass of electrical equipment;

5) the possibility of ensuring unification with ATVs equipped with ICE, in terms of drive axles, load-bearing system, suspension and steering.

- $\quad$ The scheme "Electric motor instead of ICE" has the corresponding disadvantages:

1) the impossibility of implementing identical wheel control algorithms without the use of mechanical devices.

- M "Motor-axis" (Figure 1, b), corresponds to the installation of an electric motor at the entrance to the main gear. The scheme has the following advantages:

1) the possibility of releasing usable space in the central parts of the ATV to accommodate two people in a row;

2) the ability to implement individual control algorithms without the use of mechanical devices.

The disadvantages of the "Motor-axis" scheme include:

1) to ensure the possibility of movement on the rise will have to use a re-sized rear axle motor, as well as a re-sized traction inverter;

2) a large mass of electrical equipment on board: 2 electric motors, 2 inverters, more electrical wiring [13];

3) an electrical system with a large number of electrical components will lead to an overall decrease in the reliability of an ATV;

4) a more complex cooling system for two electric motors. A greater number of hydraulic lines, including passing through the centre of the supporting system, will reduce the overall level of reliability of the ATV.

- "Electric motor-axis" (Figure 1, c), corresponds to the installation of an electric motor instead of the main gear. The scheme has the following advantages:

1) the presence of free from mechanical elements of the driveline design solutions space between the axes;

2) the ability to implement individual axis control algorithms without the use of mechanical devices;

3) the possibility of implementing "complex" types of movement, such as a u-turn.

It has the following disadvantages:

1) to ensure the possibility of movement on the rise, sloping and when traveling over rough terrain, it is necessary to use oversized electric motors, as well as oversized traction inverters;

2) a large mass of electrical equipment on board: 4 electric motors, 4 inverters, a large number of wiring;

3) an electrical system with a maximum number of electrical components will lead to a general decrease in the reliability of an ATV;

4) one posted wheel will lead to a loss of a quarter of the total power of the ATV;

5) a more complex branched cooling system for four electric motors. A greater number of hydraulic lines will lead to unreasonable complication of the design of the ATV and a decrease in the overall level of reliability.

Based on the analysis of the above advantages and disadvantages the scheme "Electric motor instead of ICE" was chosen. The choice of such a scheme is due to high rates of unification with mechanical ATVs of the family of JSC Russian Mechanics and high rates of energy efficiency. 


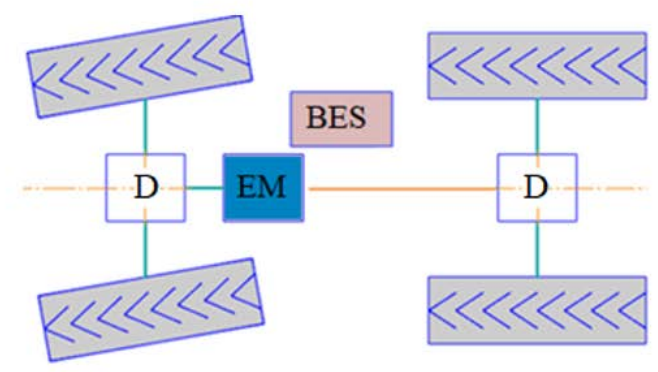

a)

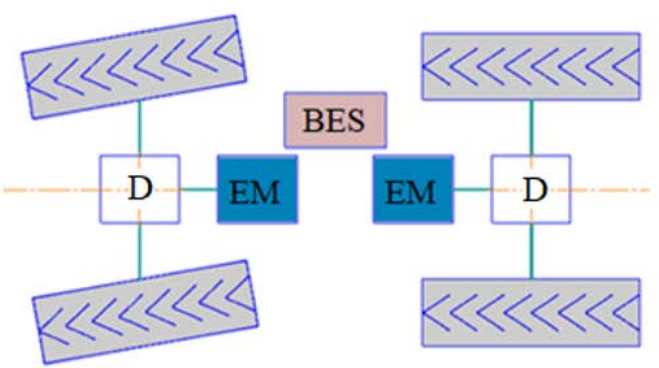

b)

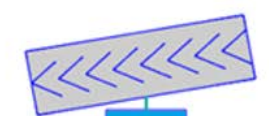

EM

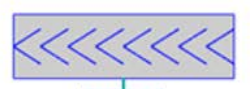

EM

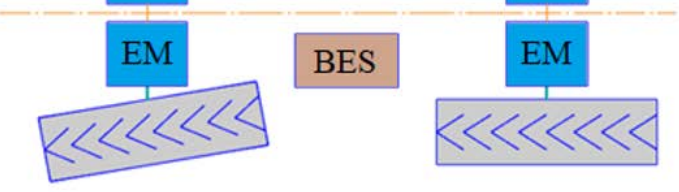

c)

Fig. 1. Electric drive schemes: a) "An electric motor instead of an internal combustion engine", b) "Motor axis", c) "Motor axis"

\section{General design solutions}

Based on the selected scheme of the traction electric motor, the general design solutions of the developed ATV was determined shown in Figure 2.

In the central part of the vehicle is an electric motor assembly with a transfer case. Above the transfer case is the motor controller. The batteries are allocated in two blocks and located in the front and rear of the ATV as shown in Figure 2. 


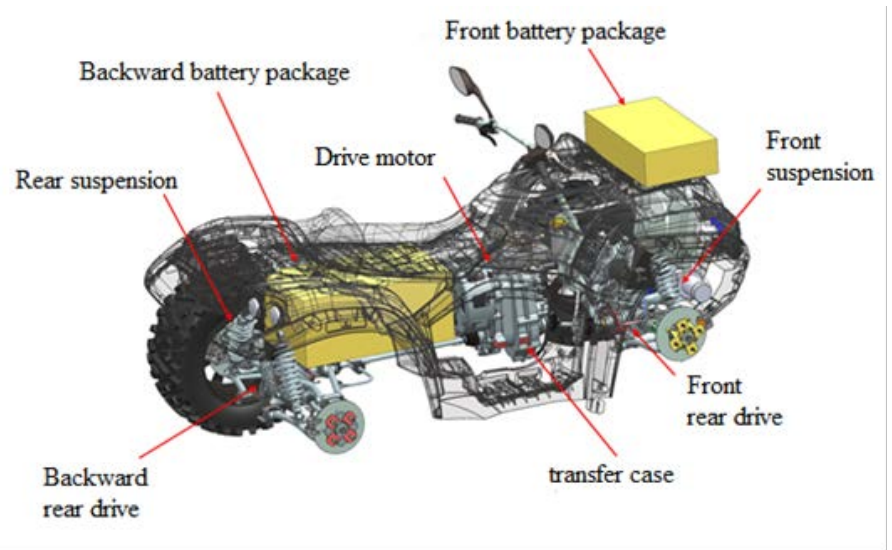

Fig. 2. General design solutions of the developed $4 \times 4$ ATV with an electromechanical driveline

\section{Conclusion}

For this developed 4x4 ATV with an electro-mechanical driveline there are many design solutions determined by the selected electric drive scheme. Based on the purpose and scope of the product being developed and the analysis of the advantages and disadvantages of the given electric drive schemes the "Electric motor instead of the internal combustion engine" scheme was chosen on the basis of which the general design solutions of the developed ATV was determined.

\section{References}

1. Larin, VV Theory of motion of all-wheel drive wheeled machines: textbook / VV Larin. - M.: Publishing house of MSTU im. N.E.Bauman, 2010 .-- 391.

2. Reshetov DN, Machine parts: Textbook for students of engineering universities. - 4th ed., Revised. and add. - M .: Mechanical Engineering, 1989 .-- 496 p .: ill.

3. Modeling of vehicle systems: Textbook / M.M. Zhileikin, G.O. Kotiev. - M .: Publishing house of BMSTU, 2017.

4. Design of car transmissions: Handbook / Under total. ed. A.I. Grishkevich. - M .: Mechanical Engineering, 1984, - 272 p.

5. V.V., Pozdeev A.V., Diakov A.S. Research and testing complex for analysis of vehicle suspension units // Procedia Engineering. 2015. Vol. 129. P. 465-470. DOI: 10.1016 / j.proeng.2015.12.15

6. Kotiev G.O., Padalkin B.V., Kartashov A.B., Dyakov A.S. Designs and development of Russian scientific schools in the field of cross-country ground vehicles building // ARPN Journal of Engineering and Applied Sciences. 2017.Vol. 1 No. 4. S. 1064-1071.

7. Kotiev G.O., Diakov A.S. Advanced development and testing of off-road vehicle // DEStech Transactions on COMPUTER SCIENCE and ENGINEERING. 2017 2nd International Conference on Computer, Mechatronics and Electronic Engineering (CMEE 2017) pp. 464-467. ISBN: 978-1-60595-532-2. DOI 10.12783 / dtcse / cmee2017 / 20021.

8. Diakov A.S., Kotiev G.O. Establishment of production of special wheel and track technology for extreme natural-climate conditions of the Arctic // MATEC Web of 
Conferences Volume 224, 30 October 2018, Article number 02096 DOI: 10.1051 / matecconf / 201822402096

9. Diakov A.S., Novikov V.V., Pozdeev A.V. The main directions of the development of snowmobiles in the Russian Federation // MATEC Web of Conferences Volume 224, 30 October 2018, Article number 02080 DOI: 10.1051 / matecconf / 201822402080

10. D.A. Chumakov, K.V. Chernyshov, V.V. Novikov, A.S. Diakov and A.S. Suchenina. Mathematical model of motor vehicle air suspension with a combined damping system. IOP Conf. Series: Journal of Physics: Conf. Series 1177 (2019) 012049. DOI: 10.1088 / 1742-6596 / 1177/1/012049.

11. V.E. Klubnichkin, A.S. Dyakov, E.E. Klubnichkin, A.Yu. Zakharov, U.Sh. Vakhidov, A.S. Suchenina and I.V. Basmanov. Experimental evaluation of speed and brake properties of domestic and foreign made utility terrain vehicles. IOP Conf. Series: Journal of Physics: Conf. Series 1177 (2019) 012048. DOI: 10.1088 / 1742-6596 / 1177/1/012048.

12. V.E. Klubnichkin, A.S. Dyakov, E.E. Klubnichkin, A.Yu. Zakharov, U. Sh. Vakhidov, A.S. Suchenina and I.V. Basmanov. Experimental evaluation of stability and controllability of domestic and foreign made utility terrain vehicles. IOP Conf. Series: Journal of Physics: Conf. Series 1177 (2019) 012045. DOI: 10.1088 / 1742-6596 / $1177 / 1 / 012045$.

13. Sosnin D.A. Electrical, electronic and autotronic equipment for cars (Avtotronika-3): Textbook for universities. M .: SOLON-PRESS, 2010, $384 \mathrm{p}$. 